\section{Nyttig om smertepumper}

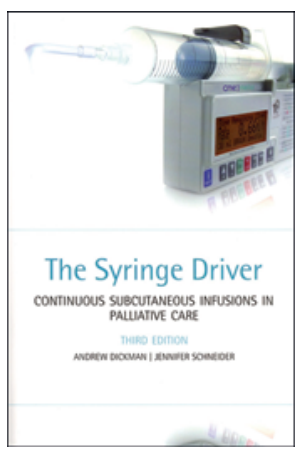
Andrew Dickman, Jennifer Schneider
The syringe driver

Continuous subcutaneous infusions in palliative care. 3. utg. $482 \mathrm{~s}$, tab, ill. Oxford: Oxford University Press, 2011. Pris GBP 25 ISBN 978-0-19-956972-4

Forfatterne er farmasøyter, fagfolk som er til uvurderlig nytte når det skal lages legemiddelblandinger for sprøytepumper, populært kalt smertepumper i Norge.

Målgruppen er leger, sykepleiere og farmasøyter som arbeider med lindrende behandling, særlig kreftpasienter i sen palliativ fase. Det er fire kapitler. De to første omhandler informasjon om bruk av sprøytepumper til kontinuerlig subkutan infusjon og de mest aktuelle legemidlene for slik behandling. De to siste kapitlene inneholder en presentasjon av de vanligste kliniske tilstandene som lindres ved hjelp av kontinuerlig subkutan infusjon, og til slutt forlikelighetstabeller for legemidler i blanding.

Umiddelbart kan boken virke avskrekkende. Den er imidlertid mest en oppslagsbok med informasjon om de enkelte aktuelle legemidlene for kontinuerlig subkutan infusjon og et stort antall forlikelighetstabeller.

Den viktigste indikasjonen for bruk av kontinuerlig subkutan infusjon er pasienter som av ulike grunner ikke lenger kan ta sine legemidler gjennom munnen. Dette gjelder ikke bare pasienter der døden er nært forestående. Bruk av kontinuerlig subkutan infusjon regnes heller ikke som mer effektivt enn peroralt inntak.

Innledningsvis beskriver forfatterne valg av infusjonssted og håndtering av problemer ved vevsreaksjoner på infusjonsstedet. De gir svar på ofte stilte spørsmål om hvilke legemidler som kan administreres med kontinuerlig subkutan infusjon, og hvilke og hvor mange som kan inngå i en blanding, og forutsetninger for god forlikelighet og stabilitet. De mest aktuelle sprøytepumpene blir også presentert. En generasjon sprøytepumper, som har vært mye i bruk i Norge, Smiths Medical MS26 (tidligere Graseby), anbefales ikke lenger, bl.a. grunnet manglende sikkerhetssystem. Fire andre, nyere pumper beskrives, men er mindre aktuelle i Norge fordi avanserte elektroniske pumper med større legemiddelreservoar er blitt vanligere hos oss.

Den alfabetiske monografien innledes med en oversikt over ekvianalgetisk doseberegning mellom ulike opioider - peroralt og parenteralt. Usikkerheten ved slik beregning understrekes og må tas hensyn til i klinisk arbeid. Oversikten inneholder flere midler og formuleringer som ikke er vanlig tilgjengelig i Norge. Men bidragsyterne gir svært nyttig informasjon om dosering, interaksjoner, blandbarhet osv., spesielt når flere legemidler skal inngå i en blanding for kontinuerlig subkutan infusjon.

De vanligste symptomene som kan lindres godt ved hjelp av kontinuerlig subkutan infusjon, er smerter, kvalme og oppkast, delirium, terminal angst og uro og sekretstagnasjon i luftveiene hos døende («ralling»). Spesielt gjennomgangen av kvalme- og oppkastfysiologi gir god forståelse for fornuftig valg av antiemetikum.

I siste kapittel er det en omfattende fremstilling av forlikelighetstabeller der alt fra to til seks legemidler inngår i samme blanding. Legemidlene er opioider, antiemetika, sedativa, antikolinergika, glukokortikoider og andre. For mange hundre ulike blandinger oppgis legemiddeldose i sprøyten, totalvolum, sluttkonsentrasjon, fortynningsmiddel, brukstid for blandingen (vanligvis 24 timer) og referanse for forlikeligheten mellom legemidlene - dokumentert ved klinisk inspeksjon eller laboratorieundersøkelse.
I vår behandlingskultur har det hittil vært lite aktuelt å bruke mer enn 2-3 legemidler i samme blanding. Et klinisk problem kan være at hvis man ønsker å endre døgndosen av ett legemiddel i en blanding, må de andre legemidlene i blandingen «følge med».

Ved bruk av våre mest aktuelle elektroniske pumper lager apotekenes sterilavdelinger vanligvis legemiddelblandinger som skal vare i mange dager. Er det behov for blandinger med mange legemidler, er det mest problematisk med forlikelighet som kan forhindre fremstilling. Denne boken gir informasjon om nye muligheter, både for farmasøyter og for leger som arbeider med syke der inntak av medikamenter gjennom munnen er blitt problematisk og begrensende for god lindrende behandling.

\section{Stig Ottesen}

Seksjon lindrende behandling

Avdeling for kreftbehandling

Oslo universitetssykehus, Ullevål

\section{Om fedme på dansk}

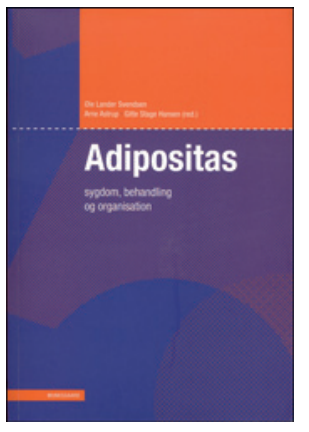

Ole Lander Svendsen, Arne Astrup,

Gitte Stage Hansen, red.

Adipositas

Sygdom, behandling og organisation. $301 \mathrm{~s}$, tab, ill. København: Munksgaard Danmark,

2011. Pris DKK 299

ISBN 978-87-628-0966-6

Denne nye læreboken er ifølge de danske redaktørene beregnet for alle som «beskæftiger sig med pleje og behandling af mennesker». De forklarer dette med at alle som har med pleie av mennesker å gjøre, også må forholde seg til de av oss som er overvektige og fete. Ambisjonen til redaktørteamet er at de fleste dermed kan finne oppdatert viten om fedme et sted, nemlig i denne boken. Det har de lyktes ganske godt med.

Boken er organisert i 14 hovedkapitler som bl.a. omfatter definisjoner av fedme, undersøkelsesmetoder, epidemiologi, anatomi og fysiologi, følgesykdommer, utredning, forebygging, behandling, organisering av behandling og forskning. 40 meget kompetente danske klinikere og forskere har bidratt. De forskjellige innleggene er relativt godt harmonisert, selv om enkelte budskap kan bli gjentatt noen ganger. Flere kapitler inneholder oversiktlige faktabokser og gode illustrasjoner og tabeller som gjør boken enkel å lese. Den kan godt brukes som lærebok, men egner seg nok best som oppslagsbok.

De første to tredelene er stort sett relevante for norske forhold. Jeg anbefaler spesielt de gode kapitlene om undersøkelsesmetoder, fettvevets anatomi og fysiologi og appetittregulering. Boken preges imidlertid av overordnede danske retningslinjer for utredning og behandling av fedme. På flere punkter avviker de en del fra våre nye, norske, nasjonale faglige retningslinjer. Kapitlene om organisering av behandling, allmennpraksis, foreninger og fedmekirurgi er mest relevante for danske lesere.

Selv om Adipositas er skrevet på dansk for dansker, anbefaler jeg den også for nordmenn med interesse for fedme og fedmerelaterte følgesykdommer.

\section{Jøran Hjelmesæth}

Senter for sykelig overvekt i Helse Sør-Øst

Sykehuset i Vestfold

Tønsberg 